\title{
Extraction and characterization of lipids from Sarcocornia ambigua meal: a halophyte biomass produced with shrimp farm effluent irrigation
}

\author{
CÉSAR S.B. COSTA ${ }^{1}$, JULIANO R.M. VICENTI ${ }^{2}$, JOAQUÍN A. MORÓN-VILLARREYES ${ }^{2}$, \\ SERGIANE CALDAS ${ }^{2}$, LIZIANE V. CARDOSO ${ }^{2}$, RICARDO F. FREITAS ${ }^{1}$ and MARCELO G.M. D'OCA ${ }^{2}$ \\ ${ }^{1}$ Instituto de Oceanografia, Laboratório de Biotecnologia de Halófitas, \\ Universidade Federal do Rio Grande/FURG, Av. Itália, Km 08, 96203-900 Rio Grande, RS, Brasil \\ ${ }^{2}$ Escola de Química e Alimentos, Laboratório Kolbe de Síntese Orgânica, \\ Universidade Federal do Rio Grande/FURG, Av. Itália, Km 08, 96203-900 Rio Grande, RS, Brasil
}

Manuscript received on January 18, 2013; accepted for publication on July 15, 2013

\begin{abstract}
Sarcocornia ambigua is a perennial glasswort, native of South America and a potential new seed-oil crop and forage for direct irrigation with salt water. Small seeds develop inside fertile segments of its cylindrical leafless shoots and, at the harvest, seeds are typically mixed with remnant cellulose material difficult to separate. This work evaluated different extraction methods and the composition of total esterified fatty acids in a meal of ground fertile shoots of $S$. ambigua, seeking for an alternative primary matter and larger yield of total lipids. The highest lipid yield was obtained with a chloroform:methanol mixture $(2: 1)(\mathrm{v} / \mathrm{v})$ (5.2\% of dry weight). The most abundant polyunsaturated fatty acids in the meal were linoleic acid (C18:2; $21.4 \%$ ) and oleic acid (C18:1; 18.3\%). Fifty six percent of the lipids in S. ambigua meal were saturated and palmitic acid (C16:0) was the main fraction (19.8\%). Long-chain fatty acids $(\geq C 20)$ represented $29.5 \%$ of the lipids. Most abundant long-chain fatty acids were behenic acid (C22:0; 7.1\%), lignoceric acid (C24:0; 5.3\%) and montanic acid (C28:0; 4.0\%). The percentage of saturated lipids in S. ambigua meal was higher than that of vegetable oils with a MUFA nutritional profile and some of these lipids have known bioactive properties.
\end{abstract}

Key words: Lipids, Long chain fatty acids, Palmitic acid, Polar solvent, $\omega 6$ acid.

\section{INTRODUCTION}

Sarcocornia ambigua (Michx.) Alonso \& Crespo (subfamily Salicornioideae, family Chenopodiaceae) is the most widely distributed perennial species in South America of a genus of small succulent halophytic shrubs, common in coastal marshes, mangroves and salt deserts (Isacch et al. 2006, Alonso and Crespo 2008), but it is also a potential new seed-oil crop and forage for direct

Correspondence to: César Serra Bonifácio Costa

E-mail: docosta@furg.br irrigation with salt water (Costa 2006, 2011, D'Oca et al. 2012). An experimental crop of $S$. ambigua in northeastern Brazil, irrigated with saline effluent from a shrimp farm, yielded an average of 8.9 fresh weight tons/hectare of aerial shoot biomass after three months of cultivation (Costa 2006, 2011). Recently, a production of 23.4 fresh-weight tons/ hectare was achieved under plentiful irrigation and saline effluent of high nitrogen content in southern Brazil (state of Rio Grande do Sul; RS) (Costa et al. 2011). These yields are within the same order as 
the results obtained with the closely related species Salicornia bigelovii (Clark 1994, El-Mallah et al. 1994, Anwar et al. 2002, Zerai et al. 2010). Members of Salicornioideae share physiological aspects and the morphology of cylindrical leafless shoots, and are commonly called glassworts. S. bigelovii is an annual glasswort commercially cultivated in the United States, Mexico, Saudi Arabia, the United Arab Emirates, Egypt, Eritrea and Pakistan, not only for seed oil production (Glenn et al. 1998, El-Mallah et al. 1994, Anwar et al. 2002, Zerai et al. 2010), but also for forage, as a by-products rich in protein and carbohydrates used for feeding chickens (Attia et al. 1997), fish (Belal and AlDosari 1999) and sheep (Kraidees et al. 1998), and in addition to being used in the human diet as well (Ventura et al. 2011).

The ellipsoid seeds of $S$. ambigua are small $(0.10 \pm 0.04 \mathrm{mg})$ and their hexane extract yielded $13 \%$ of total lipids (D'Oca et al. 2012). The seeds develop inside fertile segments of the succulent green shoots, and are only available after the senescence of shoots. At the harvest, seeds are typically mixed with debris such as soil and remnant cellulose material, which are difficult to separate. It results in a clear reduction of seed oil yield and in an increased effort with preprocessing to remove debris. However, fatty acids in seed oil are not the only lipids in plant material. Lipids can also be found in wax esters (surface shoots and leaves), glycolipids (membranes of photosynthetic tissues), phospholipids (in cellular membranes) and triglycerides (stored mostly in seeds and plant tissues) (Misra et al. 1987, Ivanova et al. 2000, Kulis et al. 2010), all feasible for synthetic biofuel and supplementation of animal feeding (Kulis et al. 2010). Thus, a larger amount of total lipids per hectare of $S$. ambigua crop might be obtained from the utilization of fertile shoot segments (with seeds) as primary matter, rather than only by seed oil extraction. The molecular structures of glycolipids and phospholipids consist of two fatty acids bonded to a glycerol, whereas triglyceride molecules have three fatty acids linked by ester bonds to a glycerol. Differently from triglycerides and other non-polar fatty acids common in seed oil, glycolipids and phospholipids are essential polar lipids with a polar head and a non-polar tail. Since the polarity of lipids affects the solubility in solvents, it is necessary to find the most efficient extraction method to dissolve the non-polar and polar lipids present in plant tissue.

There are a few studies about the quantity and composition of lipids in glasswort shoots. Shimizu et al. (2001) found $4.9 \%$ of total lipids in Salicornia herbacea shoots, whereas Kulis et al. (2010), depending on the extraction method, obtained between $3.2 \%$ and $7.1 \%$ of total lipids from shoots of Salicornia europaea and Salicornia virginica (sin. Sarcocornia perennis). Similar to their seeds, fatty acid composition of shoots of Salicornia and Sarcocornia species is dominated by polyunsaturated acids with 16 and 18 carbons, but a significant amount of saturated acids are also present (Imai et al. 2004, Kulis et al. 2010, Ventura et al. 2011), and most of the lipids found in shoots are phospholipids (Ivanova et al. 2000, 2009). EPAGRI (2008) reported the presence of $\beta$-sitosterol and stigmasterol in shoots of $S$. ambigua. Furthermore, the cake obtained after lipids extraction from $S$. ambigua shoots could be used for animal feed, due to their high percentages of protein (8\%) and ashes (27-30\%)(Augusto-Ruiz et al. 2000, Costa 2006, Medina et al. 2008), as well as the presence of several phenolic compounds (Costa et al. 2006).

This work aimed at evaluating different extraction methods, and both qualitative and quantitative compositions of total esterified fatty acids in a meal of ground fertile shoots of the perennial glasswort $S$. ambigua cultivated with saline effluent from a Litopennaeus vannamei shrimp tank in southern Brazil. 


\section{MATERIALS AND METHODS}

\section{Plant MATERIAL}

In April 2010, at the Marine Aquaculture Laboratory (EMA-FURG, RS, Brazil; 32 12' 19" S, 52 10' 45" W), shoots of seven-month-old S. ambigua were harvested at ground level from a $10-\mathrm{m}$ by $20-\mathrm{m}$ plot irrigated with saline effluent from a Litopennaeus vannamei shrimp tank. Plants were grown spaced $40 \mathrm{~cm}$ apart and watered by filling up drainage ditches once a day with 2,000 litres of effluent. During the growth period, about $740 \mathrm{~mm}$ of rainfall accumulated and average values ( \pm standard error) of soil surface (0-5 cm deep), electrical conductivity and moisture content were $5.7 \pm 2.9 \mathrm{dS} / \mathrm{m}$ and $7.8 \pm$ $3.2 \%$, respectively $(n=156)$. After harvesting, plants were dried, and apical branches with fertile segments were manually separated from vegetative shoots. These fertile shoot segments (with seeds) were then ground in mortar and pestle to a fine powder.

EXTRACTION OF LIPIDS

The total lipids of $S$. ambigua meal were estimated after extractions with non-polar (Hexane) and polar (Ethanol and Methanol) solvents, as well as a mixture of Chloroform and Methanol 2:1 (v/v). Commercial solvents (Synth, Brazil and Merck, Germany) of chromatographic grade were used for the extractions. Prior to extractions, the fine powder meal was properly washed with distilled water to removed adhered salt, dried at $50^{\circ} \mathrm{C}$ for 24 hours and subsequently weighed. All procedures of the extraction methods were performed in triplicate samples of dry meal ( $2 \mathrm{~g}$ ) with $12 \mathrm{~mL}$ of the tested solvents in a test tube. Hexane extractions were made with solvent at room temperature (Method 1; M1) and reflux (M2) for 24 hours under magnetic stirring (700 rpm) and also using Soxhlet apparatus for 4 hours (M3). Extractions using ethanol (M4) and methanol (M5) were done for 24 hours under magnetic stirring $(700 \mathrm{rpm})$ at room temperature. In all cases, the organic phase was carefully collected and the solvent evaporated under reduced pressure. The lipid fraction was dried to constant weight in an oven at $60^{\circ} \mathrm{C}$. Total lipids was also quantified according to the methodology of Bligh and Dyer (1959) for samples of S. ambigua meal washed (M6) and not washed with distilled water (M7) before the extractions. Each meal sample was put in a 12-mL mixture of chloroform:methanol $(2: 1)(\mathrm{v} / \mathrm{v})$, placed in a test tube, then stirred $(700$ $\mathrm{rpm})$ at room temperature for 20 minutes. Later the sample was centrifuged at $2000 \mathrm{rpm}$ for 5 minutes. The organic phase was carefully collected and the solvent evaporated under reduced pressure. The lipid fraction was dried to constant weight in an oven at $60^{\circ} \mathrm{C}$.

\section{FATTY ACID PROFILES}

The derivatization of the lipid fraction of S. ambigua meal was carried out according to Metcalfe et al. (1966). A lipid fraction sample ( $300 \mathrm{mg}$ ) was placed in a test tube and a $5-\mathrm{mL}$ mixture of boron trifluoridemethanol was added. The content was dissolved with $4 \mathrm{~mL}$ of $0.5 \mathrm{M}$ methanolic $\mathrm{NaOH}$, then shaken and heated for 2 minutes. To recover the fatty acid methyl esters, the derivatized mixture was washed into a separation funnel with $15 \mathrm{~mL}$ of saturated $\mathrm{NaCl}$ solution and $15 \mathrm{~mL}$ of hexane. The organic and aqueous phases were then separated. The organic phase containing the fatty esters was dried and the solvent was evaporated at $50^{\circ} \mathrm{C}$.

The fatty acid profiles were then determined in a Shimadzu gas chromatograph-mass spectrometer model GCMS-QP2010Plus equipped with a capillary column Crossbond 5\% diphenyl/95\% dimethyl polysiloxane (Restek, $30 \mathrm{~m}$ x $0.25 \mathrm{~mm}$ i.d. $\mathrm{x} 0.25 \mathrm{um}$ ). The operational parameters of the mass spectrometer were as follows: ionization voltage, $70 \mathrm{eV}$; source temperature, $230^{\circ} \mathrm{C}$; scan region, 30 $500 \mathrm{~m} / \mathrm{z}$. The interface temperature was at $280^{\circ} \mathrm{C}$. The operating conditions were as follows: injector temperature, $250^{\circ} \mathrm{C}$; He flow rate, $1,3 \mathrm{~mL} \mathrm{~min}^{-1}$ oven temperature, $80-180^{\circ} \mathrm{C}$ raised by $10^{\circ} \mathrm{C} \mathrm{min}^{-1}, 180$ - 
$330^{\circ} \mathrm{C}$ raised by $7^{\circ} \mathrm{C} \mathrm{min}^{-1}$ and injection volume of $1 \mu \mathrm{L}$. All injections were made in the split mode (split ratio 100:1). The identification of compounds was accomplished by comparing the mass spectra data with those of compounds available from the NIST library.

\section{RESULTS AND DISCUSSION}

Seven methods were used in this study to extract the lipids from the meal of ground fertile shoots of $S$. ambigua (Table I). The highest lipid yield was obtained with a chloroform:methanol mixture (5.2\% of dry weight), whereas the extracts with methanol, ethanol and hexane yielded up to $1.7 \%$, $2.8 \%$ and $3.0 \%$ of total lipids, respectively. The maximum yield is higher than values reported for shoots of S. bigelovii (2.7\% in ether extract; Kraidees et al. 1998), S. virginica $(3.2-3.5 \%$ in hexane with Soxhlet apparatus and mixture of isopropyl alcohol and hexane; Kulis et al. 2010) and $S$. herbacea (1.3-4.9\% in ether extracts; Shimizu et al. 2001, Ishikawa et al. 2002), but lower than $7.1 \%$ of $S$. europaea extract with a mixture of isopropanol and hexane (Kulis et al. 2010). It was possible to extract only $42 \%$ of the total lipids present in the $S$. ambigua meal with the nonpolar hexane solvent (using Soxhlet apparatus), which efficiently extracts triglycerides and waxes from seeds and shoots. Thus, the larger yield of solvent mixture (more polar) can be explained by additional extraction of phospholipids that make up most of the cell membranes. Ivanova et al. (2000) observed that $82.7 \%$ and $10.3 \%$ of the total lipids in S. europaea shoots were phospholipids and triglycerides, respectively. Kulis et al. (2010) highlighted the large amount of phospholipids in fertile segments of $S$. europaea, and they also extracted two times more lipids from shoots with a polar mixture of solvents than with hexane. All the above cited results contrast with very low average values of total lipids $(0.17-0.37 \%)$ found in young shoots of S. europaea collected from a Spanish salt marsh (Guil et al. 1996), young shoots of S. bigelovii from a seawater farm in China (Lu et al. 2010) and in 4-week-old shoots of Salicornia persica. and Sarcocornia fruticosa cultivated in a greenhouse in Israel (Ventura et al. 2011). All three studies used non-polar solvents for extraction (ether and hexane, respectively) and only vegetative shoots, which probably explains the small lipid yield.

TABLE I

Percentage of total lipids of Sarcocornia ambigua fertile shoot meal extracted with different methodologies.

\begin{tabular}{|c|c|c|c|c|}
\hline Method & $\begin{array}{c}\text { Solvent } \\
\text { extractor }\end{array}$ & Temperature $^{\mathrm{a}}$ & $\begin{array}{l}\text { Biomass } \\
\text { pre- } \\
\text { treatment }\end{array}$ & $\begin{array}{c}\text { Lipids } \\
(\%)\end{array}$ \\
\hline 1 & Hexane & r.t. & $\begin{array}{c}\text { washed and } \\
\text { dried }\end{array}$ & 1.4 \\
\hline 2 & Hexane & reflux & $\begin{array}{c}\text { washed and } \\
\text { dried }\end{array}$ & 1.9 \\
\hline 3 & Hexane & Soxhlet & $\begin{array}{c}\text { washed and } \\
\text { dried }\end{array}$ & 3.0 \\
\hline 4 & Methanol & r.t. & $\begin{array}{c}\text { washed and } \\
\text { dried }\end{array}$ & 1.7 \\
\hline 5 & Ethanol & r.t. & $\begin{array}{c}\text { washed and } \\
\text { dried }\end{array}$ & 2.8 \\
\hline 6 & $\begin{array}{l}\text { Chloroform- } \\
\text { Methanol, 2:1 }\end{array}$ & r.t. & $\begin{array}{c}\text { washed and } \\
\text { dried }\end{array}$ & 5.2 \\
\hline \multirow[t]{3}{*}{7} & $\begin{array}{l}\text { Chloroform- } \\
\text { Methanol, 2:1 }\end{array}$ & r.t. & dried only & 2.2 \\
\hline & & & Average & 2.6 \\
\hline & & & $\mathrm{SD}^{\mathrm{b}}$ & 1.3 \\
\hline
\end{tabular}

${ }^{a}$ r.t. - room temperature.

${ }^{\mathrm{b}} \mathrm{SD}$ - Standard deviation of the average.

Further observations can be made from Table I results. Heating increased the yield of lipid extraction by hexane (methods 1-3), and under ambient temperature $\left(\sim 22^{\circ} \mathrm{C}\right)$ ethanol solvent extracted significantly more lipids from plant meal than methanol. These results could indicate a viable process of in situ transesterification (D'Oca et al. 2011), since ethanol, which efficiently acted as polar solvent, could also be used for esterification and transesterification for biodiesel production from $S$. ambigua meal. An interesting result was the significant difference in percentage yield of extract between Methods 6 and 7. These methods contained the same plant type and same extracting polar 
solvent, but Method 7 with samples not washed with distilled water before extraction provided a $58 \%$ decrease in extracted material. This low yield was probably related to the high content of salt in $S$. ambigua tissues, where leachable sodium (mostly accumulated in cell vacuole) alone can represent $12 \%$ of the shoot dry weight (Medina et al. 2008).

The GCMS analysis of chloroform:methanol mix (2:1) extract of $S$. ambigua meal (Fig. 1) showed a quantitative fatty acid composition very similar to the seed oil of this species (D'Oca et al. 2012), although seeds did show a larger fraction of polyunsaturated fatty acids (68\%). The most abundant polyunsaturated fatty acids in S. ambigua meal were linoleic- $\omega 6$ acid (C18:2) with $21.4 \%$ and oleic acid (C18:1) with $18.3 \%$ (Table II). The linoleic- $\omega 6$ acid has medical significance, and it is a major fatty acid of edible wild plants in Spain (Guil et al. 1996). Linoleic and oleic acids are also predominant among the polyunsaturated fatty acids in shoots of $S$. europaea (Gui et al. 1996, Kulis et al. 2010) and S. bigelovii (Weete et al. 1970).
Imai et al. (2004) showed that C18:2 and C18:3 are major fatty acids of galactolipids, monogalactosyl diacylglycerol and digalactosyl diacylglycerol of S. europaea shoot, and these molecules together accounted for $40.6 \%$ of the total glycerolipids. The non-detection of linolenic- $\omega 3$ acid (18:3) in $S$. ambigua shoot meal contrasts with its high content in shoots of other glassworts, such as $S$. europaea (35.1-41.4\%; Ivanova et al. 2009), S. bigelovii (up to $47.9 \%$; Weete et al. 1970), S. persica (47.748.3\%; Ventura et al. 2011) and S. fruticosa (41.0$43.0 \%$; Ventura et al. 2011). Since linolenic acid is a minor component of $S$. ambigua seed oil (4.0\%; D'Oca et al. 2012), its absence in the meal profile was not unexpected. These observed differences may be related to the genetic background of the species or to $S$. ambigua cultivation condition, since environmental salt concentration (Ivanova et al. 2009) and temperature (Weete et al. 1970) can affect the unsaturation level of fatty acids of plant cell membranes. Further studies are necessary to verify these hypotheses.

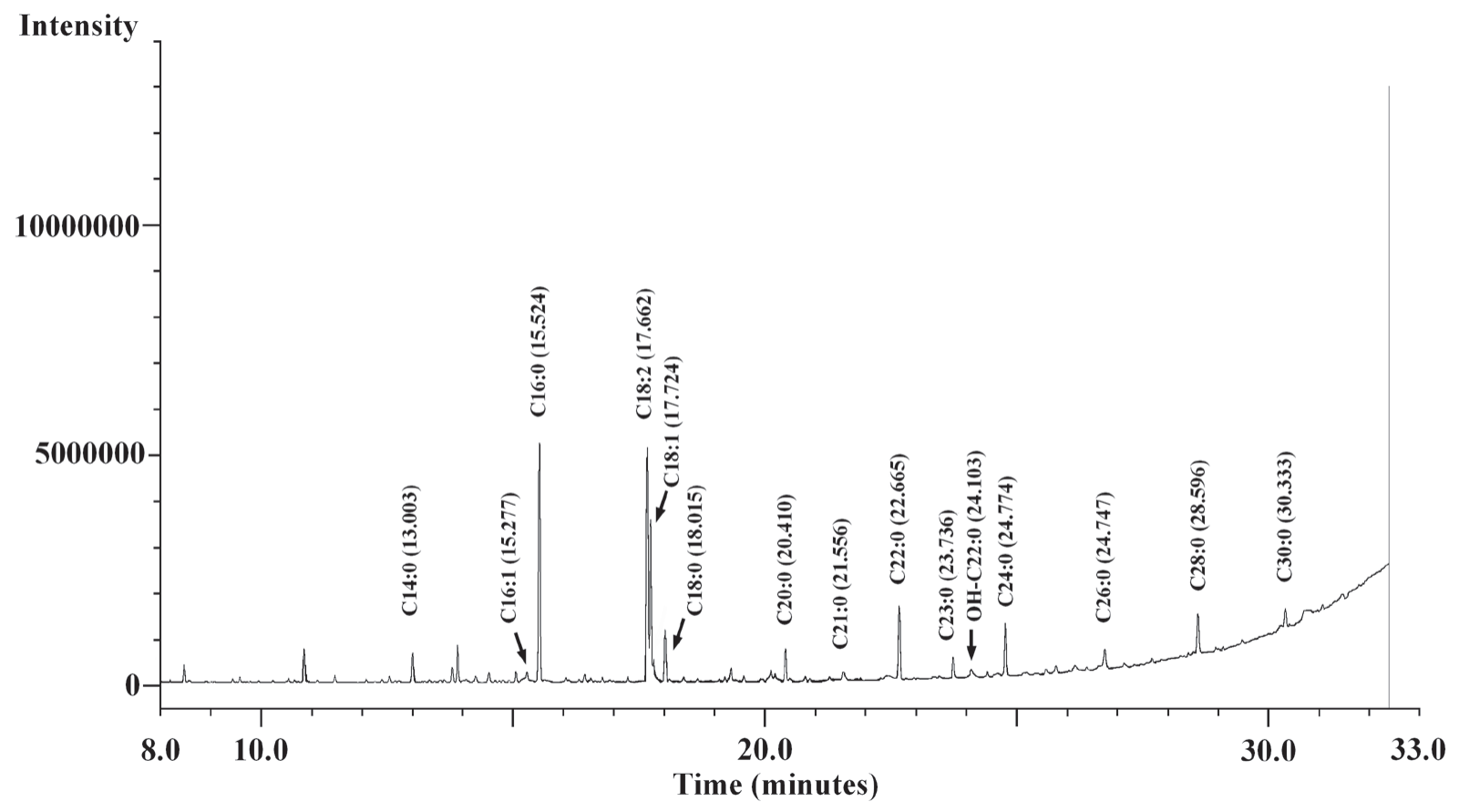

Figure 1. Gas chromatography (GCMS) of lipids from Sarcocornia ambigua fertile shoot meal extracted with a mixture of Chloroform and Methanol 2:1 (v/v). 
TABLE II

Lipid composition (\%) of Sarcocornia ambigua fertile shoot meal extracted with a mixture of Chloroform and Methanol 2:1 (v/v) $(\mathrm{RSD}<5 \%)$ and of other glasswort species (Salicornia europaea, Salicornia bigelovii, Salicornia persica and Sarcocornia fruticosa).

\begin{tabular}{|c|c|c|c|c|c|c|c|c|c|}
\hline & & & & & S. europaea & & S. bigelovii & S. persica & S. fruticosa \\
\hline Lipids & & S. ambigua & $\mathrm{SD}^{\mathrm{a}}$ & (1) & (2) & (3) & (4) & (5) & (5) \\
\hline Myristic acid & $\mathrm{C} 14: 0$ & 2.1 & 0.03 & 1.3 & $1.5-2.7$ & & 1.9 & & \\
\hline Palmitic acid & $\mathrm{C} 16: 0$ & 19.8 & 0.27 & 21.6 & $10.1-19.4$ & 24.0 & 12.0 & $19.5-19.7$ & $20.4-22.7$ \\
\hline Palmitoleic acid & C16:1 & 0.8 & 0.38 & 1.4 & & & & & \\
\hline Stearic acid & C18:0 & 4.6 & 0.02 & 2.9 & & 8.0 & 1.1 & 1.6 & 1.5 \\
\hline Oleic acid & C18:1 & 18.3 & 0.76 & 5.9 & $1.4-3.9$ & 45.0 & 14.5 & 1.6 & 1.5 \\
\hline Linoleic acid $(\omega 6)$ & C18:2 & 21.4 & 0.55 & 23.5 & $11.9-22.5$ & 23.0 & 21.5 & $22.8-24.6$ & $27.2-28.0$ \\
\hline Linolenic acid $(\omega 3)^{\mathrm{b}}$ & $\mathrm{C} 18: 3$ & - & - & 28.6 & $35.1-41.4$ & & 47.9 & $47.7-48.3$ & $41.0-43.0$ \\
\hline Arachidic acid & C20:0 & 3.0 & 0.38 & 2.4 & $0.0-0.5$ & & 0.0 & & \\
\hline Heneicosanoic acid & $\mathrm{C} 21: 0$ & 1.4 & 0.03 & & 0.0 & & & & \\
\hline Behenic acid & $\mathrm{C} 22: 0$ & 7.1 & 0.08 & 2.5 & $1.2-1.4$ & & 0.8 & & \\
\hline 2-Hydroxydocosanoic acid & $\mathrm{OH}-\mathrm{C} 22: 0$ & 1.4 & 0.06 & & & & & & \\
\hline Tricosylic acid & $\mathrm{C} 23: 0$ & 2.2 & 0.02 & & 0.0 & & & & \\
\hline Lignoceric acid & $\mathrm{C} 24: 0$ & 5.3 & 0.37 & 0.0 & $1.3-1.8$ & & 0.0 & & \\
\hline Cerotic acid & $\mathrm{C} 26: 0$ & 2.6 & 0.16 & & & & & & \\
\hline Montanic acid & C28:0 & 4.2 & 0.37 & & & & & & \\
\hline Melissic acid & $\mathrm{C} 30: 0$ & 2.3 & 0.20 & & & & & & \\
\hline Total fatty acids & & $96.5^{\mathrm{c}}$ & & 30.7 & $16.8-25.4$ & 32.0 & 15.8 & $20.7-21.4$ & $22.3-25.0$ \\
\hline Saturated fatty acids & & 56.0 & & 30.7 & $16.8-25.4$ & 32.0 & 15.8 & $20.7-21.4$ & $22.3-25.0$ \\
\hline Unsaturated fatty acids & & 40.5 & & 66.4 & $74.8-83.2$ & 68.0 & 83.9 & $75.4-76.3$ & $72.2-75.2$ \\
\hline
\end{tabular}

${ }^{a}$ SD - Standard deviation of the average; ${ }^{b}$ Included because of its predominance in other glasswort species; ${ }^{\mathrm{c}}$ Minor components, not listed, were detected to give $100 \%$.

Reference sources: (1) Gui et al. (1996), (2) Ivanova et al. (2009), (3) Kulis et al. (2010), (4) Weete et al. (1970), (5) Ventura et al. (2011).

Fifty six percent of the identified lipids in $S$. ambigua meal were saturated, and palmitic acid (C16:0) was the main fraction (19.8\%). Part of this content comes from $S$. ambigua seeds that are rich in saturated fatty acids (D'Oca et al. 2012), another significant part probably originated from C16:0 enriching phospholipids of cell membranes and glycerolipids of chloroplast membranes (Imai et al. 2004, Ivanova et al. 2009). The percentage of saturated lipids in S. ambigua meal is higher than that of vegetable oils with a MUFA nutritional profile (sensu Dubois et al. 2007), presenting about 13.4 and $36.4 \%$ of total fatty acids, and including oils from rice, peanut, oat and Jatropha. S. ambigua meal saturated lipid values are also higher than those found in shoots of edible glycophytes, which have a value usually lower than $20 \%$ of the total lipids (Guil et al. 1996), as follows: in fertile shoots of $S$. europaea (16.8-32.0\%; Kulis et al. 2010, Guil et al. 1996, Ivanova et al. 2009), in vegetative shoots of $S$. persica $(20.7-21.4 \%)$ and S. fruticosa (22.3-25.0\%)(Ventura et al. 2011). Several authors highlighted the adaptive value for halophytes of high content of saturated lipids in decreased membrane permeability for $\mathrm{Na}^{+}$ions (Leach et al. 
1990, Ivanova et al. 2000, 2009), thus preventing the $\mathrm{Na}^{+}$intake into cells from the environment and also acting as osmotic barriers against the water loss and washing out of water-soluble nutrients and osmoregulators from the cytoplasm. Additionally, high content of palmitic acid $(56 \%$ of total fatty acids) in hexane leaf extract of the mangrove bush Excoecaria agallocha was related to antibacterial and antifungal activities observed against a total of 11 microorganisms (Agoramoorthy et al. 2007).

Long-chain fatty acids $(\geq \mathrm{C} 20$ ) represented $29.5 \%$ of $S$. ambigua meal lipids, all molecules were saturated and most had an even carbon number between C20 and C30 (Table II). Among the longchain saturated fatty acids, higher amounts of behenic acid (C22:0; 7.1\%) were followed by lignoceric acid (C24:0; 5.3\%) and montanic acid (C28:0; 4.0\%). The content of long-chain fatty acids in most seed oils and shoot tissues of edible plants is much lower than that observed in S. ambigua meal (Guil et al. 1996, Dubois et al. 1987), although it has been shown that plants from the Chenopodiaceae family (e.g. sugar beet, spinach) and salt-tolerant plants have a high content of $\mathrm{C} 22$ and $\mathrm{C} 24$ in their shoots and roots (Misra et al. 1987, Imai et al. 2004, Agoramoorthy et al. 2007, Ivanova et al. 2009). For example, the amount of behenic acid (C22:0) reported in shoots of S. europaea ranged from 1.2-2.5\% (Guil et al. 1996, Ivanova et al. 2000, 2009) and for heneicosanoic acid (C21:1) reached up to $34.8 \%$ of the total lipids in Suaeda maritima leaves (Ivanova et al. 2009). Additionally, S. ambigua meal showed the presence of 2-hydroxydocosanoic acid (OH-C22:0), which together with other saturated 2-hidroxy fatty acids were found to be major components of cerebrosides from spinach leaves (Imai et al. 2004), and lack the toxic erucic acid (C22:1; included in PUFA $\mathrm{N}^{\circ} 1$ standard injected in GCMS).

The storage lipids in the fertile segments of $S$. ambigua can be accessed by using a polar solvent mixture (chloroform:methanol) and optimum temperature. Fertile shoot meal could be used as an alternative source for oil extraction, and on the basis of the composition of its esterified fatty acids, it could be recommended for animal consumption or biofuel production.

\section{ACKNOWLEDGMENTS}

This research was supported by the Conselho Nacional de Desenvolvimento Científico e Tecnológico (CNPq) under grants n. 574600/20086 and 573884/2008-0 (INCTSAL).

\section{RESUMO}

Sarcocornia ambigua é uma planta herbácea perene, nativa da América do Sul e uma nova oleaginosa com potencial para forrageira, cultivada por irrigação direta com água salgada. Suas pequenas sementes se desenvolvem dentro dos segmentos do seu caule cilíndrico sem folhas e, durante a colheita, as sementes se misturam com o material celulósico remanescente de difícil separação. Este trabalho avalia diferentes métodos de extração e a composição dos ácidos graxos esterificados na farinha de caules férteis de $S$. ambigua, visando uma matéria-prima alternativa e um maior rendimento lipídico. Um maior rendimento lipídico foi obtido utilizando uma mistura $(2: 1)(\mathrm{v} / \mathrm{v})$ de clorofórmio e metanol $(5,2 \%$ da massa seca). Os ácidos graxos poli-insaturados mais abundantes na farinha foram o ácido linoleico (C18:2; 21,4\%) e o ácido oleico (C18:1; 18,3\%). Cinquenta e seis porcento dos lipídios da farinha de $S$. ambigua foram saturados e o ácido palmítico (C16:0) foi a principal fração (19,8\%). Os ácidos graxos de cadeias longas $(\geq \mathrm{C} 20)$ representaram $29,5 \%$ dos lipídios da farinha. Os ácidos graxos de cadeias longas mais abundantes foram o ácido behênico (C22:0; 7,1\%), lignocérico (C24:0; 5,3\%) e o ácido montânico (C28:0; 4,0\%). A porcentagem de lipídios saturados na farinha de S. ambigua é significativamente maior do que os óleos comerciais com perfil nutricional MUFA e alguns dos lipídios encontrados possuem propriedades bioativas reconhecidas.

Palavras-chave: lipídios, ácidos graxos de cadeias longas, ácido palmítico, solvente polar, ácido $\omega 6$. 


\section{REFERENCES}

AgOramoorthy G, CHANDRASEKARAN M, VenKatesalu V AND HsU MJ. 2007. Antibacterial and antifungal activities of fatty acid methyl esters of the blind-your-eye mangrove from India. Braz J Microbiol 38: 739-742.

Alonso MA AND CRESPO MB. 2008. Taxonomic and nomenclatural notes on South American taxa of Sarcocornia A. J. Scott (Chenopodiaceae). Ann Bot Fennici 45: 241-254.

ANWAR F, BHANGER MI, NASIR MKA AND ISMAIL S. 2002 Analytical characterization of Salicornia bigelovii seed oil cultivated in Pakistan. J Agric Food Chem 50: 4210-4214.

Attia FM, Alsobayel AA, KriadeEs MS, Al-Saiady MY AND BAYOUMI MS. 1997. Nutrient composition and feeding value of Salicornia bigelovii Torr meal in broiler diets. Anim Feed Sci Technol 65: 257-263.

Augusto-Ruiz W, LEPSEN L AND CÁRDENAS VOC. 2000 Caracterização da fração mineral das sementes e talos da Salicornia gaudichaudiana Moq. In: Resumos do Congresso Regional de Iniciação Científica e Tecnológica em Engenharia - XV CRICTE, Rio Grande (RS): FURG, p. 27.

BELAL IH AND AL-DosARI M. 1999. Replacement of fish meal with Salicornia meal in feeds for nile tilapia Oreochromis niloticus. J World Aquacult Soc 30(2): 285-289.

BLIGH EG AND DYER WJ. 1959. A rapid method of total lipid extraction and purification. Can J Biochem Physiol 37(8): 911-917.

Clark A. 1994. Samphire: from sea to shining seed. Saudi Aramco World 45(6): 2-9.

Costa CSB. 2006. A Salicornia: uma planta que pode ser utilizada no cultivo integrado com o camarão. Panor Aquic (Braz) 98: 28-33.

CosTA CSB. 2011. Restoration of coastal habitats in Brazil using native salt marsh plants. In: Greipsson S (Ed), Restoration Ecology, Sudbury (MA. U.S.A.): Jones and Bartlett Publishers, p. 333-338.

CostA CSB ET AL. 2006. Effect of ultraviolet-B radiation on salt marsh vegetation: trends of the genus Salicornia along the Americas. Photochem Photobiol 82: 878-886.

Costa CSB, Bonilla OH, Greis G, Gesteira TCV AND PEREIRA JA0. 2011. Reduction of shrimp farm effluent by Sarcocornia ambigua perennial halophyte crop. In Abstracts of World Aquaculture 2011, Natal (RN, Brazil): World Aquaculture Society, p. 289-289.

D'OCA MGM, MORON-VILlaRREYES JA, LEMÕES JS AND CosTA CSB. 2012. Fatty acids composition in seeds of the South American glasswort Sarcocornia ambigua. An Acad Bras Cienc 84: 865-870.

D’OCA MGM, VIÊGAS CV, LEMÕES JS, MIYASAKI EK, MORÓNVillarreyes JA, Primel EG AND ABreU PC. 2011. Production of FAMEs from several microalgal lipidic extracts and direct transesterification of the Chlorella pyrenoidosa. Biomass Bioenergy 35: 1533-1538.

DuboIS V, BRETON S, LINDER M, FANNI J AND PARMENTIER M. 2007. Fatty acid profiles of 80 vegetable oils with regard to their nutritional potential. Eur J Lipid Sci Technol 109: 710-732.
El-Mallah MH, Turui T AND El-Shami S. 1994. Detailed studies on seed oil of Salicornia SOS-7 cultivated at the egyptian border of Red Sea. Grasas Aceites 45(6): 385-389.

EPAGRI. 2008. Panicêutivo - Você sabe o que significa? Agropecuária Catarinense 21(2): 13.

GLENN EP, BROWN JJ AND O'LEARY JW. 1998. Irrigating crops with seawater. Sci Am 279(2): 76-81.

Guil JL, ToriJA ME, Gimenez JJ AND Rodriguez I. 1996. Identification of fatty acids in edible wild plants by gas chromatography. J Chromatogr A 719: 229-235.

IMAI H, KINOSHITA M AND OHNISHI M. 2004. Chemical characterization of glycerolipds and cerebrosides in halophytic plant, Salicornia europaea L. J Oleo Sci 53(7): 337-341.

IsACCH JP, COSTA CSB, RODRÍGUEZ-GALlEGO L, CONDE D, ESCAPA M, GAGLIARDINI DA AND IRIBARNE OO. 2006. Association between distribution pattern of plant communities and environmental factors in SW Atlantic saltmarshes. J Biogeogr 33(5): 888-900.

ISHIKAWA N, SHIMIZU K, KoIZUMI T, SHIMIZU T AND ENISHI O. 2002. Nutrient value of saltwort (Salicornia herbacea L.) as feed for ruminants. Anim Sci 15(7): 998-1001.

IVANOVA A, NecheV J AND Stefanov K. 2000. Lipid composition of some halophyte plants from the Black Sea coast in Bulgaria. C R Acad Bulgare Sci 53(3): 83-86.

IVANOVA TV, MYASOEDOV NA, PCHELKIN VP, TSYDENDAMBAEV VD AND VERESHCHAGIN AG. 2009. Increased content of very-long-chain fatty acids in the lipids of halophyte vegetative organs. Russ J Plant Physl 56(6): 787-794.

KraideEs MS, ABOUHEIF MA, AL-SAIADY MY, TAG-ELdin A AND Metwally H. 1998. The effect of dietary inclusion of halophyte Salicornia bigelovii Torr on growth performance and carcass characteristics of lambs. Anim Feed Sci Technol 76: 149-159.

Kulis MJ, HEPP AF, PHAM PX, RiBITA D AND BOMANI BMM. 2010. Extraction and characterization of lipids from Salicornia virginica and Salicornia europaea. NASA/ Technical Memorandum-2010-216891, Washington, DC.

LEACH RP, WHEELER KP, FLOWERS TJ AND YeO AR. 1990. Molecular markers for ion compartmentation in cells of higher plants: II. Lipids composition of the tonoplast of the halophyte Suaeda maritima (L.). Dum. J Exp Bot 41(230): 1089-1094.

Lu D, Zhang Z, Wang S, Cai J, Zhou X and Zhu C. 2010. Nutritional characterization and changes in quality of Salicornia bigelovii Torr. during storage. Lebensm Wiss Technol 43: 519-524.

MEdina E, Francisco AM, WingField R AND CASAÑAS OL. 2008. Halophytism in plants of the Caribbean coast of Venezuela: halophytes and halotolerants. Acta Bot Venez 31(1): 49-80.

Metcalfe LD, Schmitz AA AND PelKa JR. 1966. Rapid preparation of fatty acid esters from lipids for gas liquid chromatography. Anal Chem 38(3): 514-515.

MisRa S, DAITA AK, Choudhury SCA AND GHosh A. 1987. Hydrocarbons and wax esters from seven species of mangrove leaves. Phytochemistry 26(12): 3265-3268. 
ShimizU K, IshikaWA N, MuranaKa S AND TANG J. 2001. Digestion trials of mixed diet with salt wort (Salicornia herbacea L.) in goats. Jpn Trop Agr 45: 45-48.

VENTURA Y, WudDineHA WA, MYrZABAYEVAB M, ALIKUlovB Z, KHOZIN-GoldBerga I, SHPIGElC M, SAMOCHAD TM AND SAGIA M. 2011. Effect of seawater concentration on the productivity and nutritional value of annual Salicornia and perennial Sarcocornia halophytes as leafy vegetable crops. Sci Hortic-Amsterdam 128: 189-196.
WEETE JD, RIVERS WG AND WEBERT DJ. 1970. Hydrocarborn and fatty acid distribution in the halophyte, Salicornia bigelovii. Phytochemistry 9: 2041-2045.

Zerai DB, Glenn EP, Chatervedi R, Lu Z, Mamood AN, NELSON SG AND RAY DT. 2010. Potential for improvement of Salicornia bigelovii through selective breeding. Ecol Eng 36: 730-739. 